\title{
CONSUMERS' RESISTANCE TO USING MOBILE BANKING: EVIDENCE FROM THAILAND AND TAIWAN
}

\author{
Chian-Son Yu \\ Shih Chien University \\ No.70, Dazhi St., Zhongshan Dist., Taipei 10466, Taiwan (R.O.C.) \\ csyu@g2.usc.edu.tw \\ Wachara Chantatub \\ Chulalongkorn Business School, Chulalongkorn University \\ No. 254, Phyathai Road, Patumwan, Bangkok 10330, Thailand \\ wachara@cbs.chula.ac.th
}

\begin{abstract}
Given that mobile banking is possibly the first commercial mobile service and a prominent example of slow-diffusing innovation, there is a need to investigate what affects people to use mobile banking from the perspective of resistant innovation. Particularly, compared with existing research predominantly adopting the perspective of innovation to investigate what affects people to adopt mobile banking, this study attempts to rectify the deficiency by conducting empirical surveys on two countries based on the theory of consumer innovation resistance. Through analyzing 1,203 Thai and 658 Taiwanese respondents, this study identified that both psychological and functional barriers significantly influenced people's resistance to using mobile banking. By breaking the psychological and functional barriers into five barriers, the generated results show that all barriers except for the traditional barrier significantly influenced the respondents' resistance to using mobile banking. The empirical results also demonstrated that the influence of each of the five barriers is unequal and differs between Thai and Taiwanese respondents. Implication culled from the study are derived to offer valuable clues for academics and practices.
\end{abstract}

Keywords: Innovation Resistance, Innovation Service, Mobile Banking 


\section{INTRODUCTION}

Although consumers' resistance to adopt innovative products or services has been noted over 30 years ${ }^{1,2,3}$ and illustrated in many real cases $4,5,6,7,8,9,10,11$, companies still often overlook consumer resistance behavioral responses when developing launch strategies for new products or services $^{9,11}$. The reason might be because current research typically adopted the perspective of consumer innovation adoption (PCIA), which assumes that consumers will gradually accept new products or services with time. The literature review indicates that a large amount of research adopted PCIA to explore what influences people to adopt innovative services or products. Meanwhile, research using the perspective of consumer innovation resistance (PCIR) to investigate what influences people to resist adopting new services or products is relatively few.

Contrary to the academic literature revealing few studies on innovation resistance and huge studies on innovation adoption, market and industry surveys have reported that most innovative services and products have failed and only a small fraction have been commercially successful $4,5,6,9,10,12,13$, $14,15,16$. That is why Laukkanen et al. ${ }^{8}$ argued that the pro-change assumption is not always true, and even untrue most of the time because most innovations have failed in the marketplace ${ }^{17}$. In line of this thinking, Kuisma et al. ${ }^{18}$ contended that research adopts the PCIA because of the biased idea that all innovations are improvements and add value for most consumers. Garcia et al. ${ }^{9}$ and Chen ${ }^{11}$ argued that even if an innovation exhibits clear advantages over existing products or services, consumers may resist the innovation when it conflicts with their belief structures, requires high learning time, or changes their routine behaviors.

Mobile banking was selected as the research subject for two reasons. First, mobile banking was possibly the first commercial mobile service ${ }^{19}$ introduced immediately following short messaging services and wireless access protocol ${ }^{20}$. Although mobile banking enables clients to access a wide range of banking services at any time and location and provides faster service than physical banking branches, mobile banking was marginally adopted in the initial period ${ }^{21}$ and the increase in the usage rate of mobile banking was substantially lower than expected ${ }^{22,23,24,25,26,27}$. Given that a slow-diffusing innovation is a resistant innovation ${ }^{9}$, understanding what causes people to resist using mobile banking is crucial for banks to design and market mobile banking services to their customers. Second, because mobile banking is based on wireless communication technology and Internet banking, mobile banking is frequently considered as an innovative technology-enabled service ${ }^{28,29,30}$. Therefore, the findings obtained from mobile banking might be useful to other technology-enabled innovation 
services. Based on the above discussion, this study aims to use PCIR to explore what affects people to resist using mobile banking.

\section{LITERATURE REVIEW}

After performing an extensive literature review on mobile banking studies, we discovered abundant literature based on the PCIA and only six studies that investigated mobile banking based on the PCIR. Considering this situation and that mobile banking is typically considered an online banking's evolution ${ }^{31}$ or extension $^{32,33}$, we expanded the literature review to studies using the PCIR to investigate factors that influence peoples' resistance to adopting online banking. As expected, there is limited literature regarding resistance to online banking; only three PCIR-based studies were discovered compared with numerous PCIA-based studies on online banking.

Drawing on the theory of innovation resistance proposed by Ram and Sheth $^{12}$, Laukkanen et al. ${ }^{8}$ summarized 18 factors into five barriers, namely usage, value, risk, traditional, and image. The objective of the theory of innovation resistance, proposed by Ram and Sheth ${ }^{12}$ and adapted from psychology and the innovation diffusion theory (IDT) of Rogers ${ }^{34}$, is to explain why customers resist innovations even when the innovations are considered necessary and desirable. Laukkanen et al. ${ }^{8}$ surveyed 1,525 usable respondents from a large Scandinavian bank and revealed that value and usage barriers were the most significant factors that influenced consumers' resistance to mobile banking, and traditional barriers were insignificant factors.

Based on studies that had indicated that consumers resist Internet banking because they do not receive enough information from the bank and lack knowledge and training concerning the use of the innovation, Laukkanen and Kiviniemi ${ }^{35}$ presented five hypotheses to test whether information offered by the bank has a negative effect on the five barriers: usage, value, risk, traditional, and image. After collecting 1,551 valid responses, Laukkanen and Kiviniemi ${ }^{35}$ tested the hypotheses by using structural equation modeling and discovered that all hypotheses were supported except for that relating to traditional barrier. That is, Laukkanen and Kiviniemi ${ }^{35}$ concluded that information offered by the bank significantly lowered the four barriers (usage, value, risk, and image) but did not significantly lower the traditional barrier.

Kusima et al. ${ }^{18}$ conducted an in-depth interview with 30 customers of a large Scandinavian bank and used the means-end approach to identify two functional barriers (usage and value barriers) and three psychological barriers (risk, traditional, and image barriers) which cause consumer 
resistance to online banking. After analyzing these barriers and interviews, Kusima et al. ${ }^{18}$ contended that some barriers are connected to Internet banking and some are connected to Internet channel. Moreover, resistance to change was determined to be a personal characteristic generating resistance to online banking and both consumer and communication characteristics may generate barriers.

Laukkanen et al. ${ }^{36}$ collected 390 valid samples from a large bank in Finland and uncovered that customers who resisted online banking thought that it would not enhance their ability to deal with financial matters, attached a negative image to the new service in general, and preferred going to their bank in person. By grouping resisters into postponers, opponents, and rejectors, Laukkanen et al. ${ }^{36}$ further discovered that the usage, value, traditional, and image barriers differed significantly among the three groups. The rejectors exhibited a much more intense and diverse resistance than the opponents, and the postponers exhibited only slight resistance.

To investigate how customers experience and perceive different types of resistance to Internet banking, Laukkanen et al. ${ }^{37}$ performed a postal survey and collected 302 Finnish bank customers who had not adopted Internet banking services in November and December 2006. Laukkanen et al. ${ }^{37}$ separated 251 valid respondents into four groups: non-resistors, functional resistors, psychological resistors, and dual resistors. They performed statistical analysis and found that the functional resistors resisted online banking mainly because of the functional characteristics of the service. The psychological resistors resisted online banking primarily because Internet banking changes their banking traditions and routines. Their study reported that the resistors preferred face-to-face services and visiting their bank in person. Through hypothesis examination, Laukkanen et al. ${ }^{37}$ determined that the four groups exhibited distinct perceptions and resistance levels regarding online banking.

Although Cruz and Laukkanen ${ }^{31}$ used TAM as a research basis, their study focused on exploring mobile banking resistance factors. By surveying 3,585 respondents who do not use any kind of mobile devices (cell phones, PDAs, or smartphones) to access electronic banking services, they discovered that the main reasons for rejecting the service are perceived cost, risk, low perceived relative advantage, and complexity. Considering that the innovation adoption process suffers from pro-change bias and resistance to change is a normal consumer response to innovations, Laukkanen and Kiviniemi ${ }^{35}$ argued that resistance to innovations and those individuals who resist change are overlooked or have received inadequate attention in literature. Additionally, in order to overcome the resistance, marketers need to identify the sources of resistance and develop strategies to reduce that 
resistance. Hence, Laukkanen and Kiviniemi ${ }^{35}$ analyzed 1,551 bank customers and found that Information and guidance offered by the bank has a significant effect on the usage barrier, value barrier, risk barrier, traditional barrier, and image barrier.

By employing a multitude of theoretical backgrounds on internet banking adoption, the theory of resistance to change, and perceived risk, Mzoughi and M'Sallem ${ }^{38}$ postulated that consumer's demographics (age, gender, and education), functional barriers (perceived usefulness, and perceived risk), and psychological barriers (dispositional RTC) would significantly affect consumers' resistance to mobile banking services. Through the 595 valid respondents, their study identified that perceived usefulness, perceived risk, dispositional resistance to change, and demographics are significantly different between the three segments (postponers, opponents, and rejectors). Recently, Yu et al. ${ }^{39}$ explored the effect of e-lifestyle on consumers' resistant barriers to use mobile banking services and found that e-lifestyle significantly moderated the effects of traditional, image, and usage barriers to consumers' resistance to using mobile banking in Thailand, while e-lifestyle significantly moderated the effects of traditional and usage barriers to resist using mobile banking in the Taiwanese survey. In their study, people's e-lifestyles are stimulated by "willingness and interests-driven e-lifestyle," "need-driven e-lifestyle," "personal propensity-driven e-lifestyle," "entertainment and sociability driven e-lifestyle," and "perceived importance-driven e-lifestyle."

\section{THEORETICAL BASIS AND HYPOTHESIS DEVELOPMENT}

The concept of consumer innovation resistance was first proposed by Sheth in $1981^{1,12,13}$. In the model of innovation resistance ${ }^{40}$, habit or behavior toward an innovation may cause two types of resistance. First, innovations which require a change in consumers' established behavioral patterns, norms, habits, and traditions are likely to be resisted. Second, innovations which in some way cause a psychological conflict or problem for consumers are likely to be resisted. Based on the theory of innovation resistance, resistance barriers were typically grouped into two core constructs: functional and psychological barriers ${ }^{1,38}$. Accordingly, the following hypotheses were posited:

H1: Psychological barriers significantly affect a person's intention to resist using mobile banking; and 
H2: Functional barriers significantly affect a person's intention to resist using mobile banking.

In contrast to Rogers' IDT, which considers consumer resistance to an innovation as a temporary response, and even emotional or illogical response $^{13}$, Sheth ${ }^{1}$ argued that the vast majority of people have no desire to change to adopt an innovation, and only a small minority of people seek change to embrace an innovation. Sheth ${ }^{1}$ theorized about consumer innovation resistance by two psychological constructs: habit/behavior toward an innovation and perceived risks associated with innovation adoption. Regarding the perceived risks associated with innovation adoption, Sheth ${ }^{1}$ and $\mathrm{Ram}^{40}$ indicated that consumers perceive three major types of risks when they encounter an innovation: (1) aversive physical, social, or economic consequence; (2) performance uncertainty; and (3) perceived side effects associated the innovation.

In the context of mobile banking, prior literature review indicates that Laukkanen et al. ${ }^{8}$ summarized 18 factors into five barriers, namely usage, value, risk, traditional, and image barriers, and concluded that the value and usage barriers were the most intense factors influencing consumers' resistance to mobile banking, and the traditional barrier was an insignificant factor in incurring consumers' resistance to mobile banking. Laukkanen and Kiviniemi ${ }^{35}$ presented five hypotheses to examine whether information offered by the bank has a negative effect on each of the barriers to adoption. After testing these hypotheses, Laukkanen and Kiviniemi ${ }^{35}$ concluded that information offered by the bank significantly lowers the usage, value, risk, and image barriers, but not the traditional barrier.

In the context of online banking, the aforementioned literature review indicates that Kusima et al. ${ }^{18}$ and Laukkanen et al. ${ }^{37}$ found that psychological and functional barriers significantly influenced people's resistance to using Internet banking. Laukkanen et al. ${ }^{37}$ argued that the psychological resistors resisted adopting online banking primarily because it changes consumers' banking traditions and routines. Laukkanen et al. ${ }^{37}$ also observed that although resistors associated negative images with Internet banking and perceived technology-enabled service as overly complicated, the main reason for their resistance was their preference for personally dealing with tellers rather than the difficulty, riskiness, or perceived useless of the online banking. Likewise, Garcia et al. ${ }^{9}$ observed that psychological and economic switching costs are the main barriers incurring consumers' negative attitudes and resistance to adopting innovations.

In addition, numerous market cases have reported that people resist a novel service or product even when the product or service is considered 
necessary and desirable ${ }^{8,12}$, or despite the service and product benefitting consumers ${ }^{9,15,16}$. In regards to why consumers resist innovative products and services, Ram and Sheth ${ }^{12}$ and Garcia et al. ${ }^{8}$ described five barriers: being incompatible with existing work flow and practices, not understanding the value of the innovation, viewing the innovation as being too risky, requiring consumers to deviate from established social norms and traditions, and a negative image.

According to the above studies, we further break the functional construct into usage, value, and risk barriers, and the psychological construct into traditional and image barriers. Therefore, the following hypotheses were posited:

H1: Psychological barriers significantly affect a person's intention to resist using mobile banking;

H1a: Traditional barriers significantly affect a person's intention to resist using mobile banking;

H1b: Image barriers significantly affect a person's intention to resist using mobile banking;

H2: Functional barriers significantly affect a person's intention to resist using mobile banking;

H2a: Usage barriers significantly affect a person's intention to resist using mobile banking;

H2b: Value barriers significantly affect a person's intention to resist using mobile banking; and

H2c: Risk barriers significantly affect a person's intention to resist using mobile banking.

\section{QUESTIONNAIRE DEVELOPMENT, SAMPLING, AND DATA ANALYSIS}

To assess the research structure and constructs effectively, items for measuring each corresponding construct were culled from the empirical literature and reworded to fit the context of mobile banking resistance. Additionally, a focus-group interview and panel discussion involving mobile banking executives and scholars were conducted to verify the research structure and hypothesis. As a result, 18 questions were developed and assessed on a five-point Likert scale ranging from 1 (strongly disagree) to 5 (strongly agree), and another five questions were used to collect respondents' basic data. A pretest was also conducted by inviting several academics and practitioners to double-check the survey questions and refine the wording. 
An online survey was used for data collection because of limited manpower and resources. After a two-month survey, 1,203 and 658 valid samples from Thailand and Taiwan, respectively, were collected. Among respondents, $534(44.4 \%)$ Thai respondents were men and $669(55.6 \%)$ were women, and 334 (50.8\%) Taiwanese respondents were men and 324 (49.2\%) were women. Table 1 shows a summary of the detailed basic data of respondents.

Table 1. The profile of samples in Thailand and Taiwan

\begin{tabular}{|c|c|c|c|c|c|}
\hline & ategories & $\begin{array}{l}\text { Number of } \\
\text { Respondents } \\
\text { (Thailand) }\end{array}$ & Percentage & $\begin{array}{l}\text { Number of } \\
\text { Respondents } \\
\text { (Taiwan) }\end{array}$ & Percentage \\
\hline Gender & Male & 534 & $44.4 \%$ & 334 & $50.8 \%$ \\
\hline Gender & Female & 669 & $55.6 \%$ & 324 & $49.2 \%$ \\
\hline & Less than 20 years old & 31 & $2.6 \%$ & 42 & $646 \%$ \\
\hline & 20-25 years old & 246 & $20.4 \%$ & 202 & $30.7 \%$ \\
\hline & 25-30 years old & 405 & $33.6 \%$ & 143 & $21.7 \%$ \\
\hline & $30-35$ years old & 246 & $20.4 \%$ & 102 & $15.5 \%$ \\
\hline & $35-40$ years old & 103 & $8.6 \%$ & 52 & $7.9 \%$ \\
\hline Age & $40-45$ years old & 64 & $5.3 \%$ & 27 & $4.1 \%$ \\
\hline & 45-50 years old & 30 & $2.5 \%$ & 37 & $5.6 \%$ \\
\hline & $50-55$ years old & 30 & $2.5 \%$ & 29 & $4.4 \%$ \\
\hline & $55-60$ years old & 24 & $2.0 \%$ & 13 & $2.0 \%$ \\
\hline & 60-65 years old & 20 & $1.7 \%$ & 3 & $0.5 \%$ \\
\hline & above 65 years old & 4 & $0.3 \%$ & 8 & $1.2 \%$ \\
\hline & Senior High Diploma or Below & 38 & $3.2 \%$ & 49 & $7.4 \%$ \\
\hline & Associate Bachelor Degree & 32 & $2.7 \%$ & 95 & $14.4 \%$ \\
\hline Education & Bachelor's Degree & 814 & $67.6 \%$ & 386 & $58.7 \%$ \\
\hline & Master's Degree & 308 & $25.6 \%$ & 115 & $17.5 \%$ \\
\hline & Ph.D. Degree & 11 & $0.9 \%$ & 12 & $2.0 \%$ \\
\hline & Student & 180 & $15 \%$ & 182 & $27.7 \%$ \\
\hline & Teacher/Education Staff & 23 & $1.9 \%$ & 42 & $6.4 \%$ \\
\hline & House Keeper & 36 & $3.0 \%$ & 24 & $3.6 \%$ \\
\hline & Government Staff & 81 & $6.7 \%$ & 24 & $3.6 \%$ \\
\hline & Policy/Military & 8 & $0.7 \%$ & 11 & $1.7 \%$ \\
\hline Occunation & Medical/Bio Industry & 17 & $1.4 \%$ & 18 & $2.7 \%$ \\
\hline Uccupation & Banking/Insurance & 105 & $8.7 \%$ & 70 & $10.6 \%$ \\
\hline & House/Restate/ & 32 & $2.7 \%$ & 56 & $8.5 \%$ \\
\hline & Construction Industry & & & & \\
\hline & Other Service Industry & 359 & $29.8 \%$ & 126 & $19.1 \%$ \\
\hline & Other Manufacturing Industry & 340 & $28.2 \%$ & 88 & $13.4 \%$ \\
\hline & Others & 15 & $1.2 \%$ & 17 & $2.6 \%$ \\
\hline & Less than NT $\$ 500,000$ & 775 & $64.4 \%$ & 383 & $58.2 \%$ \\
\hline & NT\$500,000 - 999,999 & 286 & $23.8 \%$ & 194 & $29.5 \%$ \\
\hline Annual & NT $\$ 1,000,000-1,499,999$ & 73 & $6.1 \%$ & 50 & $7.6 \%$ \\
\hline & NT\$1,500,000 - 1,999,999 & 37 & $3.1 \%$ & 18 & $2.7 \%$ \\
\hline & NT $\$ 2,000,000$ or above & 19 & $1.6 \%$ & 13 & $2.0 \%$ \\
\hline
\end{tabular}


Because the path analysis is a regression-based technique that can analyze structure models with multiple-item constructs and direct and indirect paths ${ }^{41}$, path analysis was used to test the proposed model with the hypotheses. Accordingly, partial least squares (PLS) path analysis (also known as PLS path modeling) was used to examine the hypothesized model. The PLS approach allows researchers to assess model parameters and structural path coefficients simultaneously. Table 2 shows that all factors in the measurement model exhibited adequate reliability and convergent validity because all factor loadings were greater than 0.7 , the composite reliabilities exceeded the acceptable criteria of 0.6, and the AVEs were greater than the threshold value of 0.5 in all cases. In Tables 3 and 4, the diagonal elements represent the square roots of AVE, and the off-diagonal elements are correlations between constructs. The discriminant validity was supported because Tables 3 and 4 indicate that all diagonal elements were higher than the off-diagonal elements in the corresponding rows and columns.

Table 2. Reliability and convergent validity examination of the constructs

\begin{tabular}{|c|c|c|c|c|c|}
\hline \multicolumn{2}{|c|}{ Constructs } & Items & $\begin{array}{c}\text { Factor } \\
\text { Loading }\end{array}$ & $\begin{array}{l}\text { Composite } \\
\text { Reliability }\end{array}$ & AVE \\
\hline \multirow{6}{*}{$\begin{array}{l}\text { Psychological } \\
\text { barriers }\end{array}$} & \multirow{3}{*}{$\begin{array}{l}\text { Tradition } \\
\text { barrier }\end{array}$} & TB1 & $0.905(0.892)$ & \multirow{3}{*}{$\begin{array}{c}0.799 \\
(0.910)\end{array}$} & \multirow{3}{*}{$\begin{array}{c}0.715 \\
(0.772)\end{array}$} \\
\hline & & TB2 & $0.889(0.930)$ & & \\
\hline & & TB3 & $0.737(0.810)$ & & \\
\hline & \multirow{3}{*}{$\begin{array}{l}\text { Image } \\
\text { barrier }\end{array}$} & IB1 & $0.920(0.830)$ & \multirow{3}{*}{$\begin{array}{c}0.853 \\
(0.721)\end{array}$} & \multirow{3}{*}{$\begin{array}{c}0.732 \\
(0.686)\end{array}$} \\
\hline & & IB2 & $0.894(0.927)$ & & \\
\hline & & IB3 & $0.823(0.945)$ & & \\
\hline \multirow{9}{*}{$\begin{array}{c}\text { Functional } \\
\text { barriers }\end{array}$} & \multirow{3}{*}{$\begin{array}{l}\text { Usage } \\
\text { barrier }\end{array}$} & UB1 & $0.921(0.889)$ & \multirow{3}{*}{$\begin{array}{c}0.871 \\
(0.906)\end{array}$} & \multirow{3}{*}{$\begin{array}{c}0.785 \\
(0.763)\end{array}$} \\
\hline & & UB2 & $0.899(0.904)$ & & \\
\hline & & UB3 & $0.856(0.826)$ & & \\
\hline & \multirow{3}{*}{$\begin{array}{l}\text { Value } \\
\text { barrier }\end{array}$} & VB1 & $0.893(0.882)$ & \multirow{3}{*}{$\begin{array}{c}0.806 \\
(0.912)\end{array}$} & \multirow{3}{*}{$\begin{array}{c}0.723 \\
(0.776)\end{array}$} \\
\hline & & VB2 & $0.850(0.860)$ & & \\
\hline & & VB3 & $0.803(0.902)$ & & \\
\hline & \multirow{3}{*}{ Risk barrier } & RB1 & $0.926(0.868)$ & \multirow{3}{*}{$\begin{array}{c}0.871 \\
(0.893)\end{array}$} & \multirow{3}{*}{$\begin{array}{c}0.769 \\
(0.735)\end{array}$} \\
\hline & & RB2 & $0.908(0.836)$ & & \\
\hline & & RB3 & $0.842(0.807)$ & & \\
\hline \multirow{3}{*}{\multicolumn{2}{|c|}{ Resist using mobile banking }} & RUMB1 & $0.878(0.783)$ & \multirow{3}{*}{$\begin{array}{c}0.813 \\
(0.854)\end{array}$} & \multirow{3}{*}{$\begin{array}{c}0.702 \\
(0.661)\end{array}$} \\
\hline & & RUMB2 & $0.872(0.838)$ & & \\
\hline & & RUMB3 & $0.808(0.817)$ & & \\
\hline
\end{tabular}

Note: Figures shown in parentheses are generated from Taiwanese samples.

As Table 5 displays, the generated $\mathrm{R}_{\text {adjusted were } 0.656 \text { and } 0.607 \text { and }}^{2}$ they account for the variances explaining the resistance to using mobile banking for the Thai and Taiwanese surveys, respectively. Table 5 shows that both psychological and functional barriers considerably influenced the respondents' resistance to using mobile banking. Another similarity between 
the Thai and Taiwanese respondents is that the generated path coefficients indicate that the influential power of functional barriers on resistance to using mobile banking is higher than that of psychological barriers. By dividing the psychological and functional barriers into five barriers, Table 5 displays that the generated $\mathrm{R}_{\text {adjusted }}^{2}$ remained same and all barriers except for the traditional barrier significantly influenced respondents' resistance to using mobile banking.

Table 3. Discriminant examination of the constructs for Thai samples

\begin{tabular}{ccccccc}
\hline & TB & IB & UB & VB & RB & RUMB \\
\hline TB & 0.846 & & & & & \\
IB & 0.576 & 0.856 & & & & \\
UB & 0.438 & 0.802 & 0.886 & & & \\
VB & 0.471 & 0.665 & 0.757 & 0.850 & & \\
RB & 0.549 & 0.510 & 0.396 & 0.461 & 0.877 & \\
RUMB & 0.595 & 0.702 & 0.683 & 0.702 & 0.576 & 0.838 \\
\hline
\end{tabular}

Table 4. Discriminant examination of the constructs for Taiwanese samples

\begin{tabular}{ccccccc}
\hline & TB & IB & UB & VB & RB & RUMB \\
\hline TB & 0.879 & & & & & \\
IB & 0.350 & 0.828 & & & & \\
UB & 0.580 & 0.469 & 0.873 & & & \\
VB & 0.524 & 0.308 & 0.489 & 0.881 & & \\
RB & 0.553 & 0321 & 0.481 & 0.599 & 0.857 & \\
RUMB & 0.653 & 0.433 & 0.605 & 0.638 & 0.604 & 0.813 \\
\hline
\end{tabular}

Table 5. The PLS results with moderators

\begin{tabular}{lcc}
\hline Dependent Variable & $\begin{array}{c}\text { Thai respondents } \\
\text { Resist using mobile } \\
\text { banking }\end{array}$ & $\begin{array}{c}\text { Taiwanese respondents } \\
\text { Resist using mobile } \\
\text { banking }\end{array}$ \\
\hline$R^{2}$ Adjusted & 0.656 & 0.607 \\
Psychological Barriers & $0.073^{*}$ & $0.085^{*}$ \\
Functional Barriers & $0.352^{* * *}$ & $0.227^{* * *}$ \\
\hline$R^{2}$ Adjusted & 0.656 & 0.607 \\
Tradition Barrier & 0.018 & 0.027 \\
Image Barrier & $0.112^{* *}$ & $0.127 * *$ \\
Usage Barrier & $0.458^{* * *}$ & $0.179^{* * *}$ \\
Value Barrier & $0.193^{* * *}$ & $0.272^{* * *}$ \\
Risk Barrier & $0.429^{* * *}$ & $0.168^{* * *}$ \\
\hline Note: $*$ represents $p<0.05, * *$ represents $p<0.01, * * *$ represents $p<0.001$.
\end{tabular}




\section{DISCUSSION AND IMPLICATIONS}

By investigating 1,203 Thai respondents and 658 Taiwanese respondents, this study empirically concludes that both psychological and functional barriers significantly influenced people's resistance to using mobile banking, which is consistent to the conclusions of Kusima et al. ${ }^{8}$ and Laukkanen et al. ${ }^{37}$. By breaking the psychological and functional barriers into five barriers, the generated results show that all barriers except for the tradition barrier significantly influenced respondents' resistance to using mobile banking, which is consistent to the findings of Laukkanen et al. ${ }^{37}$ and Laukkanen and Kiviniemi ${ }^{35}$. Therefore, we contend that the traditional barrier was no longer a significant factor that influenced people's resistance to using mobile banking. The reason is that ICT-enabled services has permeated and integrated with every aspect of people's lives in the e-century, which enables people used to access various ICT-enabled services. Meanwhile, in contrast to Laukkanen et al. ${ }^{37}$ that suggested that usage and value barriers were the most significant factors, this study discovered that usage, value, and risk barriers were the most significant factors.

Regarding the findings that the image barrier considerably affected consumer resistance to using mobile banking, banks are advised to change consumers' negative image about using mobile banking services by executing experiential marketing. Experiential marketing is effective in increasing willingness and changing the thoughts of consumers who have a negative image about mobile banking as long as banks have confidence that mobile banking is a really good alternative compared with other banking alternatives. In this case, consumers will become mobile banking users or even likers once they gain a positive experience and acknowledge that mobile banking can conveniently fulfill their daily business and financial requirements. Therefore, another derived implication is that providing nonusers (potential users) with a chance to try mobile banking services is an effective strategy as long as mobile banking exhibits obvious advantages over the other banking options.

Regarding the findings that the usage barrier considerably affected consumer resistance to using mobile banking, banks are advised to change consumers' perception of mobile banking services requiring learning time by designing easy-to-use mobile banking websites. In other words, designing friendly and easy-to-use mobile banking interfaces and providing step-by-step instructions to consumers on how to use banking services through mobile devices are effective strategies that help consumers overcome usage barriers. The implication is that banks should convince consumers that time, money, and learning investments are not required whenever offering an innovative service. Regarding the findings that the 
value barrier considerably affects consumer resistance to using mobile banking, banks are advised to advertise or launch campaigns to convince consumers of benefits that can be obtained using mobile banking as compared with other banking alternatives. As discussed in the beginning, although people know that mobile banking enables them to access banking services without the limitations of time and location, mobile banking was marginally adopted in its initial period and the increase in the usage rate of mobile banking was substantially lower than expected. Accordingly, except for the convenience, banks should let consumers gain solid benefits such as giving consumers reward points or cash rebate when subscribing, purchasing, or redeeming funds through mobile banking, providing consumers with instant financial consulting and other value-added services.

As regards the findings that the risk barrier considerably affected consumer resistance to using mobile banking, banks are advised to offer mobile-banking users institution-based trust (or called institution-incurred trust) and familiarity-based trust (also known as knowledge-incurred trust). The familiarity-based trust derives from personal knowledge and the experience of allowing him or her to predict the behavior of that other party. Therefore, familiarity-based trust develops over time with the accumulation of trust-relevant knowledge and experience resulting from interaction with the other party. Hence, banks are advised to enhance current users' trust and build their long-term trust by deepening mutual relationships. Once sufficient interactions between current mobile banking users and banks have been built, they will become heavy and loyal mobile banking users.

In contrast to familiarity-based trust, institution-incurred trust is an initial trust that originates from sociological theory and is defined as the willingness of people to conduct transactions based on rules and regulations. Institution-incurred trust contains two types of trust: structural assurance and situational normality. Structural assurance, also known as structural safeguards, involves legal protections, regulations, and third-party certifications $^{42,43}$. McKnight et al. ${ }^{42}$ described situational normality as an appropriately ordered setting that appears likely to facilitate successful interactions. Situational normality is defined as the notion that a banking environment is trustworthy because the "situation" (e.g., a mobile banking interface) looks and behaves in a normal and appropriate manner. Therefore, when using mobile banking services, banks must not offer an awkward or suspicious interface that requires customers to perform any unexpected or unwanted processes. Our suggestion is that banks should convince potential users that using mobile banking is protected by governmental law and regulations. 
Looking at coefficients of different barriers in Table 5, this study also noted that the influence of each of the five barriers is unequal and differs between Thai and Taiwanese respondents. For the Thai respondents, the usage and risk barriers were ranked first and second in terms of influential power, followed by value and image. Accordingly, when devising strategies aimed at persuading customers to use mobile banking, the first priority for Thai banks is to overcome the usage and risk barriers. Thai banks are advised to offer simple user-friendly mobile banking interfaces and provide step-by-step instructions on how to use banking services, which could be the most effective strategy for persuading Thai consumers to use mobile banking. Another crucial strategy for Thai banks to assist their customers in overcoming their resistance to use mobile banking is to enhance their institution-based trust and familiarity-based trust, which derives from personal knowledge and experience of allowing him or her to predict the behavior of that other party.

For the Taiwanese respondents, the value barrier was ranked as having the most influential power, followed by usage and risk (which exhibited similar levels of influential power), and then image. Therefore, when devising strategies aimed at persuading Taiwanese customers to use mobile banking, the first priority for banks is to overcome the value barrier. This result explains why market reports have indicated that the usage rate of mobile banking has grown substantially more slowly than anticipated ${ }^{39}$, despite mobile banking services being more accessible than other banking channels (e.g., no temporal or spatial limitations). Therefore, banks in Taiwan are advised to offer consumers tangible benefits (e.g., lowering the transaction fees and offering bonuses) for using mobile banking in lieu of other banking channels (e.g., physical banking branches, automatic teller machines, and Internet banking). In other words, in Taiwan, the first priority for banks is to provide tangible benefits to consumers, which could be the most effective strategy for persuading Taiwanese consumers to use mobile banking.

\section{CONCLUSIONS}

Although some studies have suggested the need for focusing on

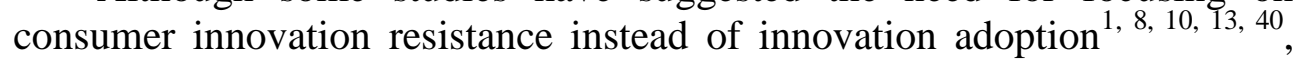
PCIA-based studies have dominated in for the past three decades and few empirical studies regarding PCIR have been conducted ${ }^{8,10}, 14,35,37,44$. Therefore, this study may rectify this deficiency by exploring the factors that influence consumers' resistance to using mobile banking. By using the theory of consumer innovation resistance as a theoretical basis, this study finds that all barriers except for the traditional barrier considerably 
influenced consumer resistance to using mobile banking in both Thailand and Taiwan. Additionally, the influence of each of these five barriers is unequal and differs between Thai and Taiwanese respondents.

As previously discussed, considerable PCIA-based research has provided banks with many valuable clues to devise their strategies. For example, many positive factors, such as perceived usefulness, perceived ease of use, perceived trust, and self-efficacy have been identified to considerably influence consumers' decisions on whether or not to adopt mobile banking. However, although banks have followed using these cues, market reports have indicated that the usage rate of mobile banking has grown substantially slower than expected, particularly when compared to other innovative mobile services. Given that marketers need to realize that a decision not to buy is a real consumption choice, understanding the reasons for this behavior could be vital in the successful development, implementation, and marketing of innovations ${ }^{38}$. Moreover, adoption only begins after a consumer has overcome the initial resistance to the innovation $^{40}$, and there is always some resistance before adoption or the ultimate rejection decision ${ }^{18}$, and adoption and resistance can also coexist ${ }^{38,40}$. The implication culled from the above discussion is that consumer resistance and adoption are two sides of whether an innovation could be successfully commercialized.

Accordingly, banks are advised to analyze consumers from not only PCIA, but also PCIR when launching innovative services. Since consumer resistance and adoption are two sides of the blade that can determine the successful commercialization of a new technology-enabled product or service, this empirical study might be useful for firms in better developing innovative strategies and services. Although mobile banking inherits attributes from mobile technology, generating the findings to other innovative mobile services still need to pay caution. Besides, compared with current research regarding mobile banking that was almost conducted in a single nation, this study enrolled both Taiwanese and Thai respondents. However, generating these findings to other countries still needs to be cautious because different countries have different cultures, social norms and living habits. Finally, to examine the difference between active resistance and passive resistance might be a worthwhile study approach. Therefore, it is encouraged to design an elaborated research structure to further investigate why and how people resist using mobile banking. Finally, further studies in different countries and mobile service sectors are necessary to reexamine the findings. 


\section{ACKNOWLEDGEMENTS}

This paper is partially supported by National Science Council of The Republic of China under Contact Number: NSC 102-2416-H-158-008.

\section{REFERENCES}

[1] J.N. Sheth, Psychology of innovation resistance: The less developed concept in diffusion research. Research in Marketing, 4(2), p273-282, 1981.

[2] L. Penaloza, and L.L. Price, Consumer resistance: A conceptual overview. Advances in Consumer Research, 20(1), p123-128, 1993.

[3] S. Oreg, Resistance to change: Developing an individual difference measure. Journal of Applied Psychology, 88(4), p680-693, 2003. http://dx.doi.org/10.1037/0021-9010.88.4.680.

[4] L. Bredahl, Determinants of consumer attitudes and purchase intentions with regard to genetically modified foods - Results of a cross-national survey. Journal of Consumer Policy, 24(1), p23-61, 2001.

[5] M. Molesworth, and J.P. Suortti, Buying cars online: The adoption of the web for high-involvement, high cost purchase. Journal of Consumer Behavior, 2(2), p155-168, 2002. http://dx.doi.org/10.1002/cb.97.

[6] D.R. Fortin, and M.S. Renton, Consumer acceptance of genetically modified foods in New Zealand. British Food Journal, 105(1), p42-58, 2003. http://dx.doi.org/10.1108/00070700310467483.

[7] S. Moldovan, and J. Goldenberg, Cellular automata modeling of resistance to innovations: Effects and solutions. Technological Forecasting \& Social Change, 71(3), p425-442, 2004. http://dx.doi.org/10.1016/S0040-1625(03)00026-X.

[8] T. Laukkanen, S. Sinkkonen, M. Kivijarvi, and P. Laukkanen, Innovation resistance among mature consumers. International Journal of Marketing, 24(7), p419-427, 2007. http://dx.doi.org/10.1108/07363760710834834.

[9] R. Garcia, F. Bardhi, and C. Friedrich, Overcoming consumer resistance to innovation. MIT Sloan Management Review, 48(1), p82-88, 2007.

[10] M. Kleijnen, N. Lee, and M. Wetzels, An exploration of consumer resistance to innovation and its antecedents. Journal of Economic Psychology, 30(2), p344-357, 2009. http://dx.doi.org/10.1016/j.joep.2009.02.004.

[11] Q. Chen, S. Anders, and H. An, Measuring consumer resistance to a new food technology: A choice experiment in meat packaging. Food 
Quality and Preference, 28(4), p419-428, 2013. http://dx.doi.org/10.1016/j.foodqual.2012.10.008.

[12] S. Ram, and J.N. Sheth, Consumer resistance to innovations: The marketing problem and its solutions. The Journal of Consumer Marketing, 6(2), p5-14, 1989. http://dx.doi.org/10.1108/EUM0000000002542.

[13] P.S. Ellen, W.O. Bearden, and S. Sharma, Resistance to technological innovations: An examination of the role of self-efficacy and performance satisfaction. Journal of the Academy of Marketing Science, 19(4), p297-307, 1991. http://dx.doi.org/10.1007/BF02726504.

[14] I. Szmigin, and G. Foxall, Three forms of innovation resistance: The case of retail payment methods. Technovation, 18(6), p459-468, 1998. http://dx.doi.org/10.1016/S0166-4972(98)00030-3.

[15] V. Mahajan, E. Miller, and Y. Wind, Introduction. In V. Mahajan, E. Miller, and Y. Wind (Eds), New product diffusion models (p3-4). Springer, New York, NY, 2000.

[16] Y. Bao, Organizational resistance to performance-enhancing technological innovations: A motivation-threat-ability framework. The Journal of Business \& Industrial Marketing, 24(2), p119-130, 2009. http://dx.doi.org/10.1108/08858620910931730.

[17] A. Fisher, Why most innovations are great big failures, Fortune, October 7, 2014.

[18] T. Kuisma, T. Laukkanen, and M. Hilunen, Mapping the reasons for resistance to Internet banking: A means-end approach. International Journal of Information Management, 27(1), p75-85, 2007. http://dx.doi.org/10.1016/j.ijinfomgt.2006.08.006.

[19] E. Scornavacca, and H. Hoehle, Mobile banking in Germany: A strategic perspective. International Journal of Electronic Finance, 1(3), p304-320, 2007. http://dx.doi.org/10.1504/IJEF.2007.011501.

[20] S. Dasgupta, R. Paul, and S. Fuloria, Factors affecting behavioral intentions towards mobile banking usage: Empirical evidence from India. Romanian Journal of Marketing, 3(1), p6-28, 2011.

[21] H. Amin, M.R.A. Hamid, S. Lada, and Z. Anis, The adoption of mobile banking in Malaysia: The case of Bank Islam Malaysia Berhad. International Journal of Business and Society, 9(1), p43-53, 2008.

[22] P. Cruz, L.B.F. Neto, P. Munoz-Gallego, and T. Laukkanen, Mobile banking rollout in emerging markets: Evidence from Brazil. International Journal of Bank Marketing, 28(5), p342-371, 2010.

[23] H. Riquelme, and R.E. Rios, The moderating effect of gender in the adoption of mobile banking. International Journal of Bank Marketing, 28(5), p328-341, 2010. http://dx.doi.org/10.1108/02652321011064872.

[24] K.B. Yap, D.H. Wong, C. Loh, and R. Bake, Offline and online 
banking - where to draw the line when building trust in e-banking? International Journal of Bank Marketing, 28(1), p27-46, 2010. http://dx.doi.org/10.1108/02652321011013571.

[25] H.F. Lin, An empirical investigation of mobile banking adoption: The effect of innovation attributes and knowledge-based trust. International Journal of Information Management, 31(1), p252-260, 2011. http://dx.doi.org/10.1016/j.ijinfomgt.2010.07.006.

[26] T. Zhou, An empirical examination of initial trust in mobile banking. Internet Research, 21(5), p527-540, 2011. http://dx.doi.org/10.1108/10662241111176353.

[27] T. Zhou, Examining mobile banking user adoption from the perspectives of trust and flow experience. Information Technology and Management, 13(1), p27-37, 2012. http://dx.doi.org/10.1007/s10799-011-0111-8.

[28] A. H. M. S. Sadi, I. Azad, and M. F. Noorudin, The prospects and user perceptions of $\mathrm{m}$-banking in the Sultanate of Omen. Journal of Internet Banking and Commerce, 15(2), p1-11, 2010.

[29] J. Sripalawat, M. Thongmak, and A. Ngramyarn, M-banking in metropolitan Bangkok and a comparison with other countries. The Journal of Computer Information Systems, 51(3), p67-76, 2011.

[30] C.S. Yu, Consumer switching behavior from online banking to mobile banking. International Journal of Cyber Society and Education, 7(1), p1-28, 2014. http://dx.doi.org/10.7903/ijcse.1108.

[31] P. Cruz, and T. Laukkanen, Mobile banking rollout in emerging markets: evidence from Brazil. International Journal of Bank Marketing, 28(5), p342-371, 2010. http://dx.doi.org/10.1108/02652321011064881.

[32] H. Yao, and C. Zhong, The analysis of influencing factors and promotion strategy for the use of mobile banking. Canadian Social Science, 7(2), p60-63, 2011. http://dx.doi.org/10.3968\%2Fj.css.1923669720110702.008.

[33] F. Maroofi, F. Kahrarian, and M. Dehghani, An investigation of initial trust in mobile banking. International Journal of Academic Research in Business and Social Sciences, 3(2), p394-403, 2013. http://dx.doi.org/10.6007/IJARBSS/v3-i9/228.

[34] E.M. Rogers, Diffusion of innovations ( $5^{\text {th }}$ edition). New York, NY: Free Press, 2003.

[35] T. Laukkanen, and V. Kiviniemi, The role of information in mobile banking resistance. International Journal of Bank Marketing, 28(5), p372-388, 2010. http://dx.doi.org/10.1108/02652321011064890.

[36] P. Laukkanen, S. Sinkkonen, and T. Laukkanen, Consumer resistance to Internet banking: Postponers, opponents, and rejectors. The International Journal of Bank Marketing, 26(6), p440-455, 2008. 
http://dx.doi.org/10.1108/02652320810902451.

[37] T. Laukkanen, S. Sinkkonen, and P. Laukkanen, Communication strategies to overcome functional and psychological resistance to Internet banking. International Journal of Information Management, 29(1), p111-118, 2009. http://dx.doi.org/10.1016/j.ijinfomgt.2008.05.008.

[38] N. Mzoughi, and W. M'Sallem, Predictors of internet banking Adoption: Profiling Tunisian postponers, opponents and rejectors. International Journal of Bank Marketing, 31(5), p388-408, 2013. http://dx.doi.org/10.1108/IJBM-10-2012-0105.

[39] C.S. Yu, C.K. Li and W. Chantatub, Analyze consumer e-lifestyles and their effects on consumer resistance to using mobile banking: Empirical surveys in Thailand and Taiwan. International Journal of Business and Information, 10(2), p17-41, 2015.

[40] S. Ram, A model of innovation resistance. Advances in Consumer Research, $14(2)$ p208-212, 1987. http://acrwebsite.org/volumes/6688/volumes/v14/NA-14.

[41] J. Wu, R.J. Tsai, C.C. Chen, and Y. Wu, An integrative model to predict the continuance use of electronic learning systems: Hints for teaching. International Journal on E-learning, 5(2), p287-302, 2006.

[42] H.D. McKnight, V. Choudhury, and C. Kacmar, Developing and validating trust measures for e-commerce: An integrative typology. Information Systems Research, 13(3), p334-359, 2002. http://dx.doi.org/10.1287/isre.13.3.334.81.

[43] D. Gefen, E. Karahanna, and D.W. Straub, Trust and TAM in online shopping: An integrated model. MIS Quarterly, 27(1), p51-90, 2003.

[44] L. Lapointe, and S. Rivard, A multilevel model of resistance to information technology implementation. MIS Quarterly, 29(3), p461-491, 2005. http://www.jstor.org/stable/25148692. 